\title{
Potensi ekstrak daun singkong (Manihot esculenta Crantz) terhadap ekspresi MMP-8 fibroblas gingiva pada model tikus dengan disfungsi ovarium dan periodontitis
}

\author{
Zahara Meilawaty ${ }^{*}$, Amandia Dewi Permana Shita1', Paramudibta Lungit \\ Kuncaraningtyas ${ }^{1}$, Agustin Wulan Suci Dharmayanti' ${ }^{1}$, Zahreni Hamzah'
}

\author{
${ }^{1}$ Departemen Biomedik, Fakultas Kedokteran Gigi Universitas Jember, Indonesia \\ *Korespondensi: zahara.fkq@unej.ac.id \\ Submisi: 20 Mei 2020; Penerimaan: 19 Agustus 2020; Publikasi online: 31 Agustus 2020 \\ DOI: $10.24198 / \mathrm{jkg} . \mathrm{v} 32 \mathrm{i} 2.27466$
}

\begin{abstract}
ABSTRAK
Pendahuluan: Disfungsi ovarium merupakan kondisi yang menimbulkan defisiensi hormon estrogen dan progesteron. Penurunan hormonal ini menyebabkan peningkatan produksi tumor necrosis factor (TNF) yang dapat memicu peningkatan produksi matriks metalloproteinase-8 (MMP-8). Periodontitis yang disebabkan oleh bakteri gram negatif akan memicu makrofag melepaskan TNF- $\alpha$ yang berkontribusi dalam pembentukan MMP-8. MMP-8 ini berperan dalam degradasi kolagen jaringan ikat gingiva. Meningkatnya MMP-8 dapat menyebabkan terjadinya periodontitis. Gejala periodontitis karena disfungsi ovarium dan induksi bakteri ini dapat diperlambat dengan bahan alam, yaitu daun singkong. Tujuan penelitian ini adalah untuk menganalisis potensi ekstrak daun singkong (Manihot esculenta Crantz) terhadap ekspresi MMP-8 fibroblas pada model tikus disfungsi ovarium dan periodontitis. Metode: Penelitian ini merupakan penelitian eksperimental laboratoris dengan post-test only control group design. Sampel yang digunakan adalah tikus Sprague-Dawley betina yang dibagi dalam 5 kelompok yaitu (1) kelompok kontrol (K), (2) Kelompok yang diinduksi bakteri Porphyromonas gingivalis dan diberi aquades, (3) Kelompok yang diinduksi bakteri Porphyromonas gingivalis dan diberi ekstrak daun singkong, (4) Kelompok yang diberi perlakuan ovariektomi dan diberi aquades, (5) Kelompok yang dilakukan ovariektomi dan diberi ekstrak daun singkong. Pengambilan jaringan gingiva setelah tahap euthanasia dilakukan untuk pembuatan preparat histopatologi dengan pewarnaan imunohistokimia. Pengamatan dan penghitungan ekspresi MMP-8 dilakukan dengan menggunakan software ImageJ dan Immunoratio. Hasil: Hasil analisis data one-way ANOVA, ekspresi MMP-8 fibroblas gingiva menunjukkan perbedaan yang signifikan $(p=0,000)$. Hal ini menunjukkan bahwa ekstrak daun singkong dapat menurunkan ekspresi MMP-8 fibroblas gingiva tikus yang mengalami disfungsi ovarium dan periodontitis diinduksi $P$. gingivalis. Simpulan: Ekstrak daun singkong (Manihot esculenta Crantz) dapat menurunkan ekspresi MMP-8 sel fibroblas gingiva pada model tikus disfungsi ovarium dan periodontitis.
\end{abstract}

Kata kunci: Disfungsi ovarium, periodontitis, ekspresi MMP-8, ekstrak daun singkong.

Potential of cassava (Manihot esculenta Crantz) leaf extract on MMP-8 expression of gingival fibroblast in rats model with ovarian dysfunction and periodontitis

\section{ABSTRACT}

Introduction: Ovarian dysfunction is a condition that causes estrogen and progesterone deficiency. This hormonal decrease causes an increase in the production of Tumour Necrosis Factor (TNF), which can trigger an increase in the production of matrix metalloproteinase-8 (MMP-8). Periodontitis caused by gram-negative bacteria will trigger macrophages to release TNF- $\alpha$, which contributes to the formation of MMP-8. MMP-8 plays a role in collagen degradation of the gingival connective tissue. An increase in MMP8 can cause periodontitis. Periodontitis symptoms due to ovarian dysfunction and bacterial induction can be slowed down by natural ingredients, such as cassava leaf. The purpose of this study was to analyse the potential of cassava leaf extract (Manihot esculenta Crantz) on MMP-8 expression of gingival fibroblast in rats model with ovarian dysfunction and periodontitis. Methods: This study was an experimental laboratory with post-test only control group design. The samples were female Sprague-Dawley rats divided into five groups: (1) control group (K); (2) Porphyromonas gingivalis induced group and given aquadest; (3) Porphyromonas gingivalis induced and given cassava leaf extract; (4) Group with ovariectomy treatment and given aquadest; (5) Group with ovariectomy treatment and given cassava leaf extract. Gingival tissue retrieval after the euthanasia was carried out for the histopathology preparations by immunohistochemical staining. Observation and calculation of MMP-8 expressions were performed using Image $J$ and Immunoratio software. Results: The results of the one-way ANOVA analysis of MMP-8 expression of gingival fibroblasts showed a significant difference $(p=0.000)$; thus cassava leaf extract reduce the MMP-8 expression of gingival fibroblasts of rats with ovarian dysfunction and P. gingivalis induced periodontitis. Conclusion: Cassava (Manihot esculenta Crantz) leaf extract can reduce the MMP-8 expression of gingival fibroblast cells in rats' model with ovarian dysfunction and periodontitis.

Keywords: Ovarian dysfunction, periodontitis, MMP-8 expression, cassava leaf extract. 


\section{PENDAHULUAN}

Disfungsi ovarium merupakan suatu kondisi penurunan fungsi ovarium yang dapat berdampak pada anovulasi dan gangguan siklus menstruasi, yang ditandai dengan perubahan kadar hormon seksual dan pituitary, terutama estrogen dan Follicle Stimulating Hormon (FSH). ${ }^{1}$ Perubahan hormon akan mempengaruhi kondisi rongga mulut terutama jaringan periodontal. Beberapa penelitian menunjukkan bahwa perubahan hormon estrogen pada wanita akan menyebabkan perubahan lingkungan rongga mulut, seperti proporsi sel imun, kadar sitokin dan kadar mineral di jaringan periodontal. Perubahan lingkungan ini mempengaruhi proses diferensiasi dan adapatasi seluler jaringan periodontal serta mengubah efektivitas barrier epitel terhadap bakteri. Defisiensi estrogen pada disfungsi ovarium menyebabkan peningkatan infiltrasi leukosit dan sitokin peradangan, yang memicu peningkatkan degradasi kolagen jaringan periodontal. ${ }^{1-4}$

MMP-8 merupakan salah satu enzim yang terlibat dalam degradasi kolagen jaringan periodontal. MMP-8 diproduksi terutama di sumsum tulang dan diekspresikan dalam neutrofil, fibroblas gingiva, sel endotel, sel epitel, sel plasma, makrofag, dan sel tulang. ${ }^{5}$ Ekspresi dan aktivasi MMP terhadap kerusakan jaringan periodontal yang menurunkan matriks jaringan ikat ini dirangsang oleh TNF- $\alpha$. Ketika konsentrasi TNF- $\alpha$ meningkat, maka produksi MMP juga akan semakin tinggi. Konsentrasi TNF- $\alpha$ dalam sampel serum dan biopsi jaringan gingiva pada pasien dengan periodontitis lebih tinggi dibandingkan dengan orang sehat. ${ }^{6}$

Periodontitis merupakan salah satu penyakit pada jaringan periodontal yang disebabkan oleh bakteri Gram negatif seperti Porphyromonas gingivalis. Komponen bakteri dari periodontopatogen, seperti lipopolisakarida (LPS), peptidoglikan, asam lipoteichoic, dan protease, dapat menginduksi peradangan. LPS yang dihasilkan oleh bakteri Gram negatif akan mengaktifkan respon imun. Makrofag akan memicu pelepasan TNF- $\alpha$ yang berkontribusi terhadap degradasi jaringan dan resorpsi tulang yaitu dengan menstimulasi pembentukan MMP.5,7

Berbagai kondisi negatif yang dialami tubuh pada fase menopause dan periodontitis dapat dicegah ataupun diperlambat dengan bahan alam yang berperan sebagai antiinflamasi. Bahan alam tersebut salah satunya adalah daun singkong (Manihot esculenta Crantz). Singkong merupakan tanaman pangan tahunan di daerah tropis yang tumbuh dan beradaptasi dengan baik menghadapi perubahan iklim. Batang, daun, dan umbi singkong juga dapat dimanfaatkan untuk berbagai industri, terutama pada daunnya yang dapat digunakan sebagai makanan dan diolah menjadi obat herbal. Daun singkong memiliki kandungan senyawa flavonoid, vitamin $\mathrm{C}$, triterpenoid, tannin, serta saponin. 8,9 Dosis ekstrak daun singkong yang dipakai dalam penelitian ini adalah 179,2 mg/kgBB. Hal tersebut sesuai dengan penelitian terdahulu yang dilakukan oleh Nisa et al. ${ }^{10}$ serta Meilawaty dan Kusumawardani1 ${ }^{11}$ yang menunjukkan bahwa ekstrak daun singkong $179,2 \mathrm{mg} / \mathrm{kgBB}$ memilik efek antiinflamasi dan efektif menurunkan ekspresi TNF- $\alpha{ }^{10,11}$ Tujuan penelitian ini adalah untuk menganalisis potensi ekstrak daun singkong (Manihot esculenta Crantz) terhadap ekspresi MMP-8 fibroblas pada model tikus disfungsi ovarium dan periodontitis.

\section{METODE}

Ethical clearence untuk prosedur perlakuan terhadap hewan coba dilakukan di Unit Etika dan Advokasi, Fakultas Kedokteran Gigi, Universitas Gadjah Mada dan telah disetujui dengan nomor 00356/KKEP/FKG-UGM/EC/2020. Jenis penelitian ini adalah eksperimental laboratoris dengan the post test only control group design. Populasi penelitian yang digunakan adalah tikus putih dari galur Sprague Dawley (Rattus norvegicus) betina, umur 2-3 bulan dengan berat badan \pm 200 gram, tikus dalam keadaan sehat ditandai dengan respon gerakan aktifnya dan tidak cacat, dan belum pernah digunakan untuk penelitian sebelumnya.

Identifikasi tanaman singkong dilakukan di Lembaga IImu Pengetahuan Indonesia (LIPI) melalui Balai Konservasi Tumbuhan (BKT) Kebun Raya Purwodadi, Malang, Jawa Timur. Ekstrak daun singkong dibuat dengan metode maserasi. Daun singkong (Manihot esculenta Crantz) yang digunakan berasal dari daerah Kreongan, Kabupaten Jember. Daun singkong yang dipetik adalah daun ke-5 dari pucuk sebanyak 450 gram. Daun singkong dicuci bersih, lalu dipotong kecilkecil dan dikeringkan dengan cara dianginkan 
selama 2 hari pada suhu ruang yang tidak terkena cahaya matahari secara langsung. Selanjutnya dikeringkan di oven pada suhu $40^{\circ} \mathrm{C}$ selama 24 jam penuh. Berat daun singkong kering setelah dilakukan pengovenan menjadi 238,54 gram. Daun singkong yang sudah kering dihaluskan dan diayak menggunakan ayakan 80 maze sehingga didapatkan serbuk halus sebanyak 207,25 gram. Serbuk halus daun singkong dimaserasi dengan etanol $96 \%$ dengan rasio simplisia:pelarut sebesar 1:6 (250gram:1.5 liter) selama 3 hari dan dilakukan pengadukan setiap 24 jam. Selanjutnya, larutan dipekatkan dengan rotary evaporator dengan suhu $50^{\circ} \mathrm{C}$ dan putaran $90 \mathrm{rpm}$ sehingga menjadi ekstrak daun singkong (Manihot esculenta Crantz) berbentuk semi solid dengan dosis $179,2 \mathrm{mg} /$ kgBB sebanyak 20 gram. Prosedur maserasi ini berdasarkan modifikasi dari Meilawaty. ${ }^{11,12}$

Hewan coba dibagi menjadi 5 kelompok yaitu (1) kelompok kontrol (K), (2) Kelompok yang diinduksi bakteri Porphyromonas gingivalis dan diberi aquades, (3) Kelompok yang diinduksi bakteri Porphyromonas gingivalis dan diberi ekstrak daun singkong, (4) Kelompok yang dilakukan ovariektomi dan diberi aquades, (5) Kelompok yang dilakukan ovariektomi dan diberi ekstrak daun singkong. Tiaptiap kelompok terdiri dari 3 ekor tikus putih betina. Pada kelompok 1 dan 3, dilakukan induksi bakteri $P$. gingivalis pada sulkus gingiva bagian bukal dan lingual gigi molar pertama kiri bawah dengan dosis masing-masing bagian 5mg/0,05 ml PBS (Phospate Buffer Saline) dan diberikan 3 hari sekali selama 2 minggu menggunakan tuberculine syringe dengan ukuran jarum 30 gauge. ${ }^{13}$ Pada kelompok disfungsi ovarium, disfungsi ovarium melalui prosedur ovariektomi pada hewan percobaan dilakukan pembedahan pada bagian dorsal secara bilateral dengan insisi tranversal dengan ukuran 0,5-1 cm menggunakan scalpel blade nomor 11 sebagai mimicking kondisi menopause. Tidak adanya ovarium karena prosedur ovariektomi pada hewan coba dapat menginduksi penurunan drastis hormon estrogen. Keadaan defisiensi estrogen terjadi setelah masa tunggu 4 minggu. ${ }^{1}$

Setelah tikus mengalami periodontitis dan disfungsi ovarium dengan prosedur ovariektomi, tikus diberikan ekstrak daun singkong. Ekstrak daun singkong diberikan dalam bentuk larutan dengan dosis $179,2 \mathrm{mg} / \mathrm{kgBB}$ secara per oral, sebanyak 2 $\mathrm{ml}$ setiap 2 kali sehari (setiap pukul 8.00 dan pukul
18.00) menggunakan sonde lambung. Prosedur tersebut dilakukan berdasarkan pada volume normal lambung tikus yaitu 3-5 ml. Pemberian ekstrak daun singkong dilakukan selama 7 hari. Pada hari ke-8 dilakukan dekapitasi pada tikus. Setelah itu rahang bawah tikus diambil dan difiksasi dengan larutan buffer formalin. Dekalsifikasi menggunakan larutan asam formiat $10 \%$ selama 14 hari, kemudian dibuat preparat histologi dengan pewarnaan imunohistokimia. Pengamatan dan penghitungan ekspresi MMP-8 dilakukan dengan menggunakan aplikasi ImageJ dan Immunoratio pada tiga lapang pandang yang berbeda dengan hasil penghitungan berupa persentase (gambar 1). ${ }^{14}$ Kemudian dilakukan analisis data dengan uj one-way ANOVA.

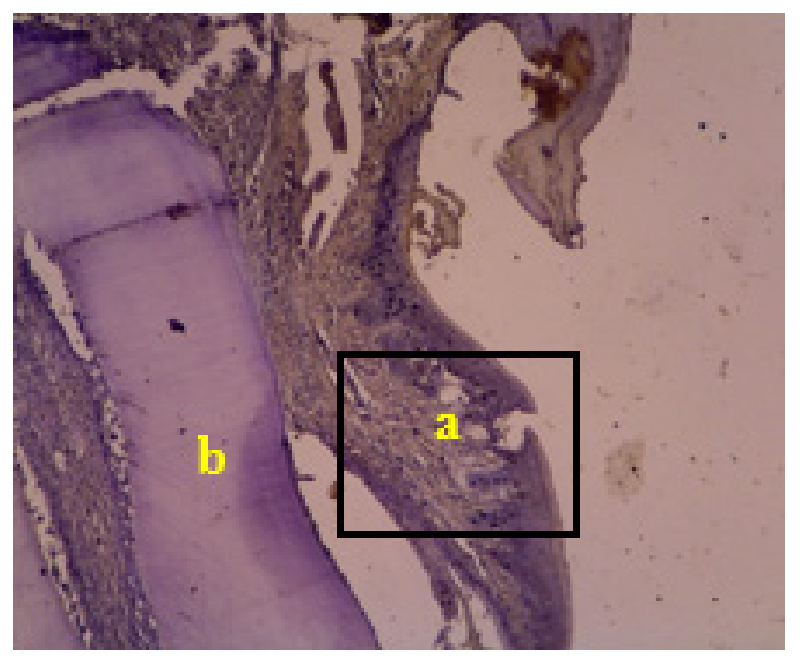

Gambar 1. Gambaran histologi preparat jaringan gingiva, perbesaran 100x dengan pewarnaan IHC: a) Gambaran gingiva (bagian yang diamati), b) Gigi.

\section{HASIL}

MMP-8 merupakan enzim kolagenolitik yang terlibat dalam regulasi peradangan. Hasil penelitian menunjukkan ekspresi MMP-8 pada fibroblast gingiva hewan coba yang diinduksi $P$. gingivalis dan mengalami disfungsi ovarium. Ekpresi MMP-8 pada fibroblast gingiva tampak adanya gambaran coklat pada sel fibroblast di jaringan gingiva (gambar 2).

Hasil penelitian menunjukkan ekspresi MMP8 pada fibroblast gingiva tertinggi tampak pada kelompok yang diinduksi $P$. gingivalis dan diberi aquadest $(37,3 \%)$, sedangkan ekspresi terendah tampak pada hewan coba disfungsi ovarium yang diberi esktrak daun singkong $(21,1 \%)$ (gambar 3). Data hasil penelitian yang diperoleh dilakukan 

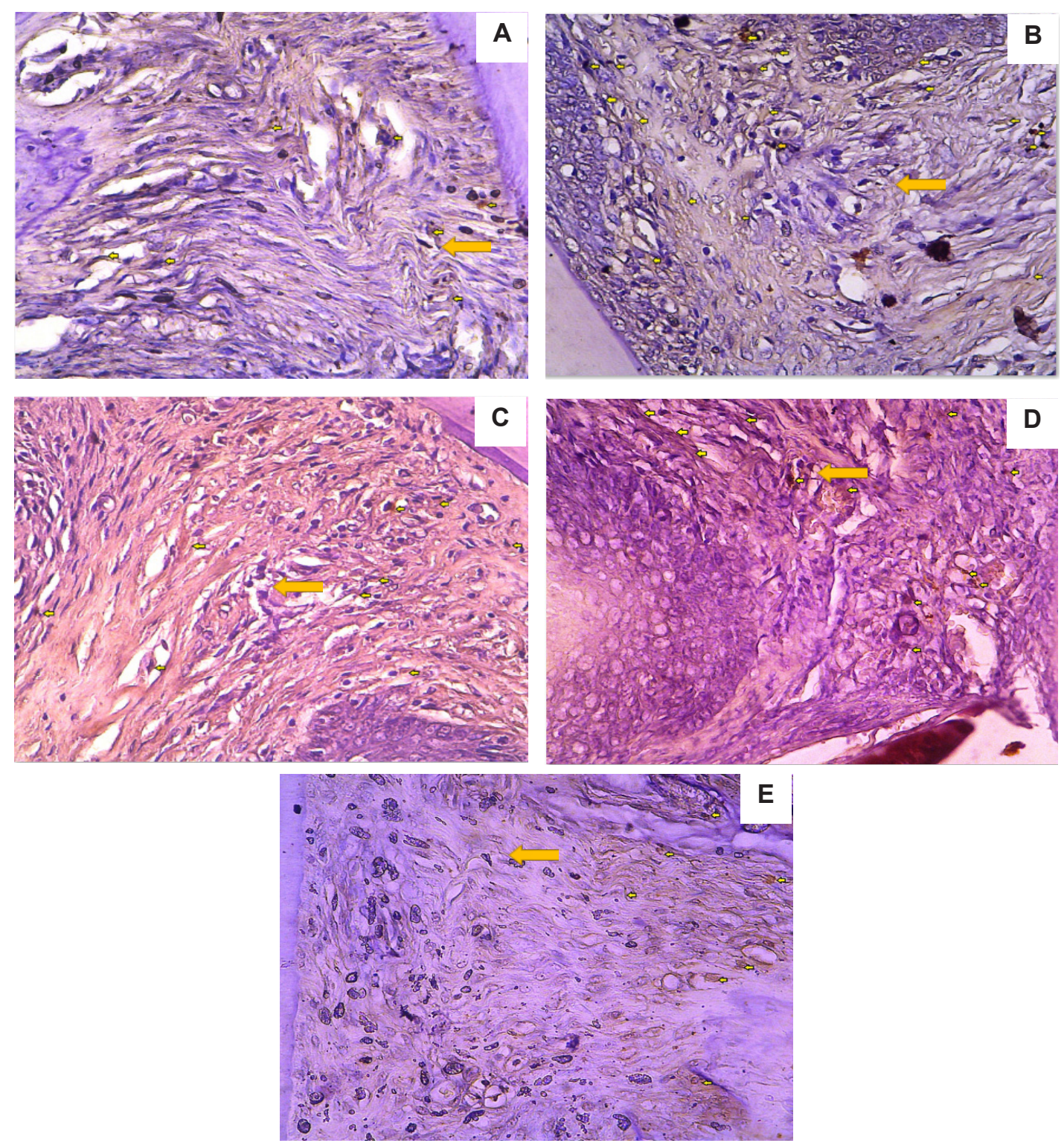

Gambar 2. Gambaran histologis jaringan gingiva tikus dengan perwarnaan IHC perbesaran 400x: a) Kelompok kontrol; b) Kelompok tikus induksi Pg yang diberi aquades; c) Kelompok tikus induksi Pg yang diberi ekstrak daun singkong; d) Kelompok tikus disfungsi yang diberi aquades; e) Kelompok tikus disfungsi yang diberi ekstrak daun singkong. Tanda panah kuning menunjukkan sel-sel fibroblas yang mengekspresikan MMP-8.

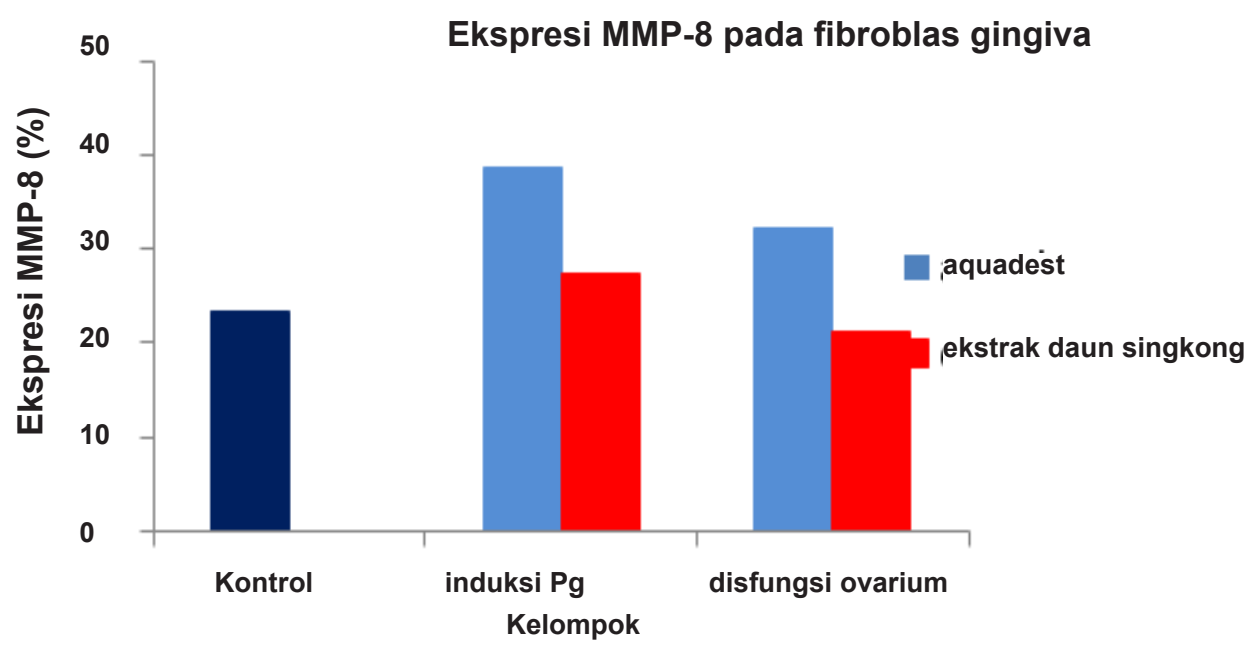

Gambar 3. Diagram batang rata-rata ekspresi MMP-8 fibroblas gingiva tikus. 


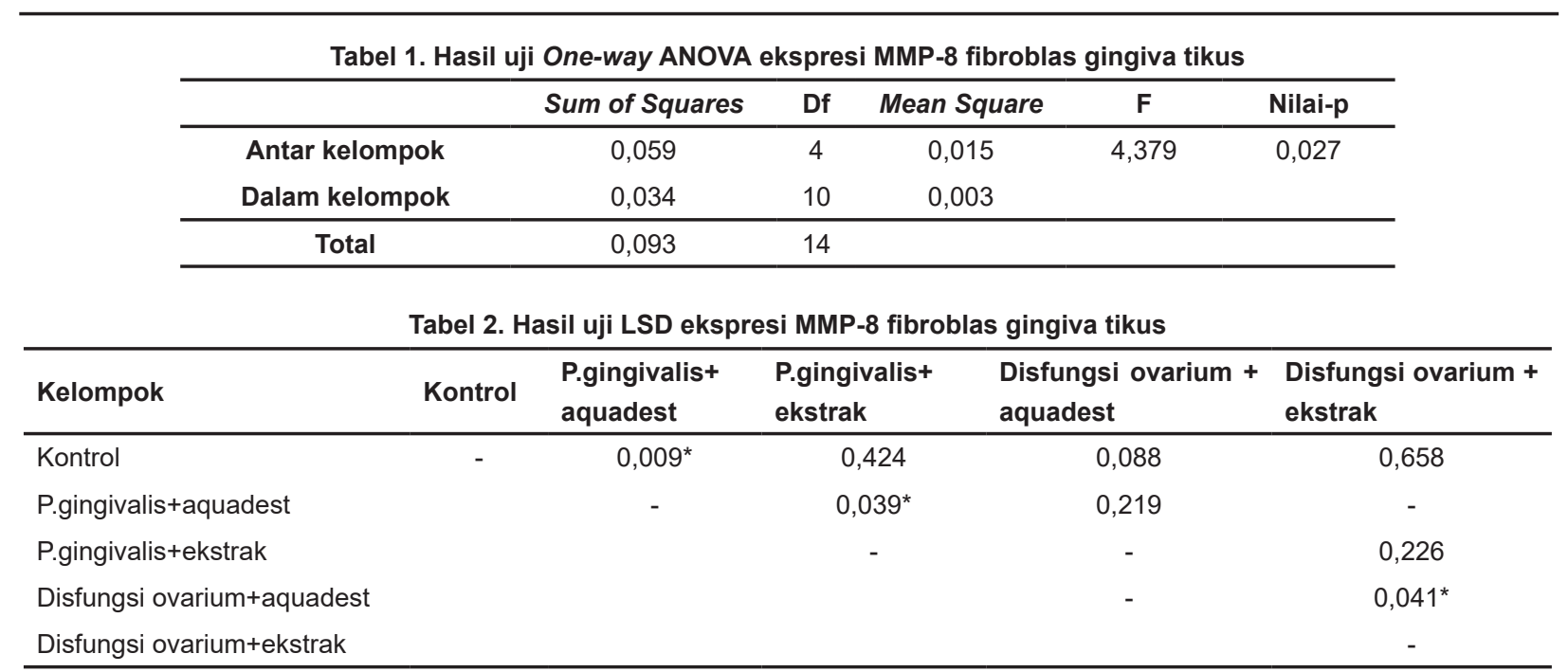

uji normalitas menggunakan Shapiro-Wilk dan uji homogenitas menggunakan uji Levene. Hasil Shapiro-Wilk menunjukkan semua data berdistribusi normal dengan nilai signifikan $>0,05$, dan hasil uji Levene menunjukkan data homogen dengan nilai signifikan $>0,05$ yaitu 0,160 . Selanjutnya dilakukan uji parametrik menggunakan One-way ANOVA untuk mengetahui perbedaan seluruh kelompok. Hasil uji One-way ANOVA disajikan pada Tabel 1.

Tabel. 1 menunjukkan bahwa nilai signifikansi (Sig)<0,05, yaitu 0,027 menjelaskan bahwa terdapat perbedaan signifikan, minimal terdapat satu pasang kelompok yang berbeda signifikan. Uji selanjutnya yaitu Least Significant Difference (LSD) untuk mengetahui perbedaan signifikan antarkelompok, disajikan pada Tabel 2 berikut ini.

Tabel 2 memperlihatkan perbedaan ekspresi MMP-8 pada fibroblast gingiva hanya tampak antara kelompok kontrol dengan kelompok yang diinduksi $P$. gingivalis dan diberi aquadest $(\mathrm{p}=0,009)$; kelompok yang diinduksi $P$. gingivalis dan diberi aquadest dengan kelompok yang diinduksi $P$. gingivalis dan diberi esktrak daun singkong $(0,039)$; kelompok hewan disfungsi ovarium yang diberi aquadest dengan kelompok hewan disfungsi ovarium yang diberi esktrak daun singkong $(p=0,041)$.

\section{PEMBAHASAN}

Hasil penelitian menunjukkan bahwa ekspresi MMP-8 tertinggi pada kelompok hewan coba yang diinduksi $P$. gingivalis dan diberi aquadest $(37,3 \%)$. Hal tersebut mungkin dikarenakan $P$. gingivalis menyebabkan kerusakan jaringan kolagen gingiva melalui peningkatan aktivitas MMP-8. Penelitian sebelumnya menunjukkan bahwa $P$. gingivalis menyebabkan degradasi kolagen pada kultur fibroblast gingiva. ${ }^{15}$ Selain itu, Bozkurt dkk menyatakan bahwa LPS $P$. gingivalis dapat menginduksi peradangan melalui peningkatan sitokin proinflammatory. Sitokinsitokin ini menyebabkan pengaktivan enzim kolagenase (metaloproteinase) termasuk MMP8 , yang berakibat pada peningkatan degradasi kolagen pada kultur fibroblast gingiva manusia. ${ }^{16}$

Penelitian ini juga menunjukkan bahwa kelompok hewan coba periodontitis dan disfungsi ovarium mempunyai ekspresi MMP-8 yang sama (gambar 3). Diduga, hal ini terjadi karena periodontitis dan disfungsi ovarium menginduksi peradangan di jaringan periodontal, dan tingkat peradangannya setara diantara kedua kelompok tersebut. Induksi $P$. gingivalis dan perubahan hormonal akibat disfungsi ovarium kemungkinan dapat menyebabkan kelainan pada jaringan periodontal yang tercermin dari ekspresi MMP-8 fibroblas gingiva yang cukup tinggi. Induksi bakteri P.gingivalis pada gingiva tikus akan menstimulasi sel-sel inflamasi seperti PMN untuk mensekresikan mediator inflamasi dan enzim misalnya $\mathrm{PGE}_{2}$, TNF- $\alpha$, dan MMP dalam jumlah banyak. Pelepasan TNF- $\alpha$ dipicu oleh siklooksigenase (COX)-2 dan $\mathrm{PGE}_{2}$ yang merupakan hasil biosintesis asam arakhidonat melalui jalur siklooksigenase, diketahui dapat meningkatkan respon inflamasi. Hal ini menyebabkan daerah peradangan menjadi membesar. PMN diaktifkan lebih lanjut dan MMP-8 aktif (aMMP-8) diproduksi, sehingga dapat meningkatkan degradasi matriks 
ekstraseluler jaringan ikat dan mempercepat perkembangan lesi ${ }^{17,18}$, di sisi lain, disfungsi ovarium menyebabkan perubahan hormonal yang secara tidak langsung dapat menyebabkan periodontitis. Pengamatan dilakukan pada minggu keempat setelah ovariektomi pada penelitian ini, merujuk pada penelitian sebelumnya yang menyatakan perubahan hormonal dan seluler sudah mulai terjadi pada minggu keempat pasca ovariektomi. ${ }^{1,13,19,20}$ Beberapa penelitian menyebutkan bahwa perubahan hormon seks wanita dapat mengubah lingkungan dan respon jaringan periodontal terhadap plak mikroba sehingga memicu peradangan dan kerusakan jaringan periodontal. ${ }^{3,4,21}$

Hasil penelitian ini juga menunjukkan hewan coba disfungsi ovarium yang diberi esktrak daun singkong mempunyai ekspresi MMP-8 diantara kelompok penelitian $(21,1 \%)$. Hal ini kemungkinan ekstrak daun singkong mempunyai komponen aktif yang mampu menekan ekspresi MMP-8 melalui penekanan peradangan dan overekspresi dari sel imun yang terlibat dalam peradangan. Daun singkong mempunyai kandungan flavonoid, saponin, tannin, triterpenoid, dan vitamin $\mathrm{C}$ yang berperan sebagai antiinflamasi, antibakteri, dan antioksidan. Penelitian sebelumnya menunjukkan bahwa ekstrak daun singkong mampu menurunkan ekspresi sitokin proinflamasi TNF-alfa dan COX2. ${ }^{11,12}$ Penurunan kadar sitokin proinflamasi ini akan menurunkan aktivitas degradasi kolagen oleh enzim MMP-8. Ekspresi dan aktivasi MMP-8 terhadap kerusakan fibroblast jaringan periodontal dirangsang oleh sitokin proinflamasi seperti TNF- $\alpha$. Ketika konsentrasi TNF- $\alpha$ meningkat, maka produksi MMP juga akan semakin tinggi. ${ }^{5,22,23}$

Selain itu, rendahnya ekspresi MMP-8 pada kedua model hewan yang diberi ekstrak daun singkong kemungkinan disebabkan oleh flavonoid yang terkandung pada ekstrak daun singkong berperan sebagai antiinflamasi dengan jalan memblokir siklus siklooksigenase dan lipoksigenase yang mengubah asam arakhidonat menjadi prostaglandin. Hambatan pada jalur siklooksigenase menyebabkan terjadinya penurunan produksi prostaglandin sehingga akan mengurangi permeabilitas vaskuler, vasodilatasi pembuluh darah, dan aliran darah lokal sehingga terjadinya penurunan jumlah sel radang neutrofil dan mediator inflamasi, seperti IL-1, IL-6, IL-8, dan
TNF- $\alpha$ pada jaringan yang mengalami inflamasi. Hal ini menyebabkan proses inflamasi berlangsung lebih singkat. Penurunan TNF- $\alpha$ pada jaringan yang mengalami inflamasi dapat menurunkan stimulasi fibroblas gingiva untuk memproduksi MMP-8. ${ }^{12,24-26}$

Kandungan lain daun singkong yang kemungkinan berperan pada penurunan ekspresi MMP-8, yaitu saponin yang dapat berfungsi sebagai antibakteri dengan mengganggu stabilitas membran sel bakteri sehingga menyebabkan bakterilisis. Saponin juga diketahui memiliki efek sebagai fitoestrogen untuk terapi gejala menopause. ${ }^{25,26}$ Terpenoid berperan dalam aktivitas antibakteri dengan cara pemecahan membran oleh komponen lipofilik. Mekanisme kerja tanin sebagai antibakteri yaitu menghambat enzim reverse transkriptase dan DNA topoisomerase sehingga sel bakteri tidak dapat terbentuk. ${ }^{27,28}$

Kandungan dari daun singkong yang berperan dalam antiinflamasi dan antibakteri ini menyebabkan sel-sel inflamasi yang bermigrasi menjadi terbatas, ekspresi MMP-8 dapat ditekan, dan tanda-tanda klinis peradangan pun berkurang. Dengan demikian, ekstrak daun singkong ini efektif menurunkan ekspresi MMP-8 sehingga tidak menyebabkan degradasi kolagen yang lebih besar dan dapat menekan gejala klinis periodontitis. Namun, pemberian ekstrak daun singkong yang hanya berlangsung 7 hari, belum optimal menurunkan ekspresi MMP-8 sampai setara dengan kelompok tikus yang sehat. Meskipun ekstrak daun singkong dalam penelitian ini masih belum optimal dalam menurunkan ekspresi MMP-8, akan tetapi ekstrak daun singkong ini mempunyai potensi sebagai bahan antioksidan dan antiinflamasi. Potensi ini kemungkinan dapat menurunkan resiko terjadinya penyakit periodontal yang dapat berdampak pada disfungsi ovarium. Penelitian ini masih memerlukan kajian lebih lanjut potensi ekstrak daun singkong dengan berbagai dosis, sehingga nantinya bisa dijadikan sebagai terapi alternatif infeksi peridontal dan disfungsi ovarium yang poten.

\section{SIMPULAN}

Ekstrak daun singkong (Manihot esculenta Crantz) dapat menurunkan ekspresi MMP-8 sel fibroblas gingiva pada model tikus disfungsi ovarium dan periodontitis. 


\section{DAFTAR PUSTAKA}

1. Suci-Dharmayanti AW, Ermawati T, Febrianto B. Ovarian failure affected leukocytes profile in peripheral blood and gingival fluid (in vivo study). In: The $2^{\text {nd }}$ International Conference in Health Sciences (ICHS). 2017. h. 1-8.

2. Afnita N, Amin MN, Suci-Dharmayanti AW. Identifikasi deoksipiridinolin pada saliva wanita usia perimenopause. Stomatognatic JKG 2014;11(1):1-5.

3. Wulan A, Dharmayanti S, Kusumawardani B. Deoxypyridinoline and mineral levels in gingival crevicular fluid as disorder indicators of menopausal women with periodontal disease. Dent J Maj Kedok Gi 2017;50(32):131-7. DOI: 10.20473/j.djmkg.v50.i3.p131-137.

4. Dharmayanti AWS, Suhartini, Kusumawardani B. Status kesehatan rongga mulut wanita suku Osing. Medic Hosp J Clin Med 2019;6(2):71-9. DOI: $10.36408 / \mathrm{mhj} \mathrm{cm} . v 6 \mathrm{i} 2.386$.

5. Sorsa $T$, Hernandez-Rios $P$, Hernandez $M$, Tervahartiala $\mathrm{T}$, Leppilahti $\mathrm{J}$, Kuula $\mathrm{H}$, et al. Oral fluid matrix metalloproteinase (MMP)-8 as a diagnostic tool in chronic periodontitis. Met Med. 2016;3:11. DOI: 10.2147/MNM.S89245.

6. Anbinder AL, Moraes RM, Lima GMG, Oliveira FE, Campos DRC, Rossoni RD, et al. Periodontal disease exacerbates systemic ovariectomy-induced bone loss in mice. Bone 2016;83:241-7. DOI: 10.1016/j. bone.2015.11.014.

7. Mysak J, Podzimek S, Sommerova P, Lyuya-Mi Y, Bartova J, Janatova T, et al. Porphyromonas gingivalis: Major periodontopathic pathogen overview. J Immunol Res 2014(1):476068. DOI: $10.1155 / 2014 / 476068$.

8. Soto JC, Ortiz JF, Perlaza-Jiménez L, Vásquez AX, Lopez-Lavalle LAB, MathewB, etal.Agenetic map of cassava (Manihot esculenta Crantz) with integrated physical mapping of immunityrelated genes. BMC Genomics 2015;16(1):116. DOI: 10.1186/s12864-015-1397-4.

9. Hasim, Falah S, Dewi LK. Effect of Boiled Cassava Leaves (Manihot esculenta Crantz) on Total Phenolic, Flavonoid and its Antioxidant Activity. Curr Biochem 2016;3(3):116-27. DOI: 10.29244/cb.3.3.116\%20-\%20127.

10. Nisa VM, Meilawaty Z, Astuti P, Gigi FK, Unej UJ. The Effect of Cassava Leaves Extract (
Manihot esculenta ) on Gingival Wound Healing Rats. Artik IIm Has Penelit Mhs. 2013;1-7.

11. Meilawaty Z, Kusumawardani B. Effect of Cassave leaf flavonoid extract on TNF-\&\#945; expressions in rat models suffering from periodontitis. Dent J Maj Ked Gi 2016;49(3):137. DOI: 10.20473/j.djmkg.v49.i3.p137-142.

12. Meilawaty Z, Dharmayanti AWS, Prafitasari D. The effect of cassava (Manihot esculenta) leaf extract on COX-2 expression in the neutrophil cell culture exposed to the lipopolysaccharide of Escherichia coli (in-vitro study). Padj J Dent 2019;31(1):60. DOI: 10.24198/pjd. vol31no1.16950.

13. Dharmayanti AWS, Hamzah Z, Meilawaty $Z$, Novita M, Ermawati T, Febrianto B, et al. Ovarian Dysfunction Induced Porphyromonas gingivalis Infection Enhances the Risk of Metabolic Syndrome (in vivo study). Malaysian J Med Heal Sci 2019;15(suppl 7):45. DOI: 10.4049/jimmunol.1800321.

14. Susilowati S. Peran matriks metaloproteinase-8 pada cairan krevikuler gingiva selama pergerakan gigi ortodontik. J Dentomaxillof Sci 2010;9(1):47-54.

15. Dharmayanti AWS, Kusumawardani B. Identification TNF-alfa, MMP-2, and Deoxypyridinoline in Gingival Cell Culture Exposed LPS of Pg. Forkinas FKG, Univ Jember. 2019. h. 63.

16. Bozkurt SB, Hakki SS, Hakki EE, Durak Y, Kantarci A. Porphyromonas gingivalis Lipopolysaccharide Induces a Proinflammatory Human Gingival Fibroblast Phenotype. Inflammation. 2017;40(1):144-53. DOI:10.1007/s10753-016-0463-7

17. Kusumastuti E, Handajani J, Susilowati $H$, Kedokteran F, Institut G, Kesehatan I, et al. Ekspresi COX-2 dan Jumlah Neutrofil Fase Inflamasi pada Proses Penyembuhan Luka Setelah Pemberian Sistemik Ekstrak Etanolik Rosela (Hibiscus sabdariffa) (studi in vivo pada Tikus Wistar). Maj Ked Gi J Indo 2014;21(1):139. DOI: $10.22146 /$ majkedgiind.8778.

18. Prasetya RC. Ekspresi dan Peran Siklooksigenase-2 dalam Berbagai Penyakit di Rongga Mulut. Stomatognatic 2015;12(1):16.

19. Benedusi V, Martini E, Kallikourdis M, Villa A, Meda C, Maggi A. Ovariectomy shortens the life span of female mice. Oncotarget 


\section{5;6(13):10801-11. DOI: $\underline{10.18632 /}$ oncotarget.2984}

20. Gameiro CM, Romão F, Castelo-Branco $C$. Menopause and aging: Changes in the immune system - A review. Maturitas. 2010;67(4):31620. DOI: $10.1016 / j$.maturitas.2010.08.003

21. Abraham A, Pullishery F. The Effect of Menopause on the Periodontium-AReview. JBR J Interdiscip Med Dent Sci. 2015;03(02):79-82. DOI: $10.4172 / 2376-032 X .1000170$.

22. Balli U, Cetinkaya BO, Keles GC, Keles ZP, Guler S, Sogut MU, et al. Assessment of MMP-1, MMP-8 and TIMP-2 in experimental periodontitis treated with kaempferol. J Periodontal Implant Sci. 2016;46(2):84-95. DOI: 10.5051/jpis.2016.46.2.84.

23. Desarda H, Gaikwad S. Matrix metalloproteinases \& implication in periodontitis- A Short Review. J Dent Allied Sci. 2013;2(2):66-70. DOI: 10.4103/22774696.159288.

24. Meilawaty Z. Efek ekstrak daun singkong (Manihot utilissima) terhadap ekspresi COX-2 pada monosit yang dipapar LPS E. coli. Dent J
(Maj Ked Gi) 2013;46(4):196-201.

25. Napimoga MH, Clemente-Napimoga JT, Macedo CG, Freitas FF, Stipp RN, Pinho-Ribeiro $F A$, et al. Quercetin inhibits inflammatory bone resorption in a mouse periodontitis model. J Nat Prod. 2013;76(12):2316-21.

26. Resende FA, de Oliveira APS, de Camargo MS, Vilegas W, Varanda EA. Evaluation of Estrogenic Potential of Flavonoids Using a Recombinant Yeast Strain and MCF7/BUS Cell Proliferation Assay. PLoS One. 2013;8(10):1-7.

27. Apriasari ML, Endariantari $A$, Oktaviyanti IK. The effect of $25 \%$ Mauli banana stem extract gel to increase the epithel thickness of wound healing process in oral mucosa. Dent J Maj Ked Gi 2015;48(3):150. DOI: 10.20473/j.djmkg.v48. i3.p150-153

28. Mulyanti S, Laela DS, Julaeha E, Suwargiani AA, Aripin D. Formulation of mouth rinse from the essential oils of lime (Citrus aurantifolia) and its inhibitory efficacy on the growth of Streptococcus mutans-in vitro. Padjadjaran J Dent. 2020;32(1):39. DOI: 10.24198/pjd. vol32no1.25486. 